\title{
STOP THE BEACH RENOURISHMENT, INC. $v$ FLORIDA DEPARTMENT OF ENVIRONMENTAL PROTECTION: AN AVULSION OF LITTORAL RIGHTS
}

\author{
by Jeffrey Partlow*
}

\section{Introduction}

A land being littoral ${ }^{1}$ 'often constitutes its chief value and desirability. ${ }^{2}$ In many cases, the littoral

rights incident to the ownership of the land were the principal, if not sole, inducement leading to its purchase ... and the reason for the price charged by the seller. ${ }^{3}$

Florida has 2276 miles of tidal shoreline, ${ }^{4} 1197$ miles of coastline, ${ }^{5}$ and 825 miles of beaches. ${ }^{6}$ The state is home to over 18.8 million people, ${ }^{7}$ attracts approximately 80 million visitors each year, ${ }^{8}$ and has a population density of more than four times the national average. ${ }^{9}$ Based on these facts and the premium often paid for beach front property, it is easy to see why defining littoral rights is vital to both the Florida economy and people who own land abutting navigable waters. It is also easy to understand why so many disputes

* Third year JD student, Capital University Law School, Columbus, Ohio, USA.

The term 'littoral owner' refers to the ownership of property abutting a 'coast or shore of an ocean, sea, or lake.' B Garner Black's law dictionary (2009) 1018; Bd of Trustees of the Internal Improvement Trust Fund v Sand Key Assocs, Ltd, 512 So. 2d 934936 (Fla. 1987). The term 'riparian owner' refers to the ownership of property along the bank of a river or stream. Garner (n 1 above) 1441; Sand Key 512 So. $2 d$ 936. 'Cases and statutes, however, have used 'riparian owner' broadly to describe all waterfront owners.' Sand Key 512 So. 2d 936. This note specifically addresses the rights of littoral owners and will use the term 'littoral' whenever possible.

2 Thiesen v Gulf la. \& Ala. Ry. Co 78 So 491507 (Fla. 1918).

3 Thiesen 78 So. 491507.

$4 \quad$ M Kilbourn \& HM Hujsa The Florida domicile handbook: vital information for new Florida residents (2009) 112.

5 B Brooke The everything guide to coastal Florida (2007) 20.

6 See Florida Department of Environmental Protection, "Florida shoreline length information according to beaches and shores technical and design memorandum 89 - 1, 5th Edition, December 1993, entitled beach conditions in Florida: a statewide inventory and identification of the beach erosion problem areas in Florida by Ralph R. Clark' (2012) 1, available at http://www.dep.state.fl.us/ beaches/publications/pdf/fl_beach.pdf.

7 US Census Bureau '2010 Census Data' http://quickfacts.census.gov/qfd/states/ 12000.html (accessed 23 January 2011).

8 'Oil aside, Florida holds its own in tourism' Sarasota Herald-Tribune 25 August 2010 D1.

9 US Census Bureau (n 7 above). 
have arisen between littoral property owners and the state, ${ }^{10}$ which owns the land under navigable waters below the mean high-water line. ${ }^{11}$

Historically, littoral property owners in Florida have had a vested right to accretions, ${ }^{12}$ subject to the doctrine of avulsion. ${ }^{13}$ Florida's Beach and Shore Preservation Act provides for elimination of this vested right without the occurrence of an avulsive event or any other event that would justify its elimination. ${ }^{14}$ Specifically, the Act authorises and provides procedures for the restoration of beaches determined critically eroded by the Florida Department of Environmental Protection (the 'Department'). ${ }^{15}$ When a beach restoration project is undertaken by the state, the Act eliminates the littoral owner's right to accretions upon the state setting and recording an erosion control line. ${ }^{16}$

In Stop the Beach Renourishment, Inc. $v$ Florida Department of Environmental Protection, ${ }^{17}$ the United States Supreme Court upheld Florida's Beach and Shore Preservation Act against a facial constitutional challenge. ${ }^{18}$ The Court held that the Act's elimination of the right to accretions does not constitute a taking because littoral owners' right to accretions is inferior to the state's right to fill. ${ }^{19}$ In erroneously upholding the Act, the Court miscategorised the background principles of Florida property law and contributed to the continued erosion of littoral rights in Florida. Considering that 398.6 miles of beaches were considered critically eroded in June $2011,{ }^{20} \mathrm{a}$ significant portion of littoral owners in Florida are now in jeopardy of

See 'Beaches a major playground for controversy' Sarasota Herald-Tribune 13 March 2010. Similar disputes over the rights of littoral property owners have arisen in states throughout the country. See, eg, City of New York $v$ Realty Assocs., 176 NE 171 (N.Y. 1931); Fowler v Wood, 85 P. 763 (Kan. 1906).

11 Fla. Const. art. X, § 11

12 'Accretion is the gradual and imperceptible addition of soil to the shore of waterfront property.' Bd. of Trs. of the Internal Improvement Tr. Fund v Medeira Beach Nominee, Inc., 272 So. 2d 209211 (Fla. Dist. Ct. App. 1973). A 'gradual and imperceptible' change is one where 'witnesses may see from time to time that progress has been made, [however,] they could not perceive it while the process was going on.' St. Clair Cnty. v Lovingston, 90 US (23 Wall.) 4668 (1874). 'Reliction' or 'dereliction' is an increase of the land by a gradual and imperceptible withdrawal of any body of water.' $B d$. of Trs. of the Internal Improvement Tr. Fund v Sand Key Assocs., Ltd., 512 So. 2d 934936 (Fla. 1987). For purposes of this note, the term 'accretions' will be used to refer to accretion, reliction, and dereliction, and the processes in which each occurs.

13 See part 3.2 Littoral owners have a vested right to accretions below. Avulsion is the opposite of accretion; Lovingston 90 US (23 Wall.) 68; it 'is the sudden or perceptible loss of or addition to land by the action of the water or a sudden change in the bed of a lake or the course of a stream.' Sand Key 512 So. $2 \mathrm{~d} 936$.

14 See Fla. Stat. § 161.011-161.45 (2010); parts 2.2 \& 3.3 below.

15 See part 2.2 below.

16 See part 2.2 below.

17 Stop the Beach Renourishment, Inc. $v$ Florida Department of Environmental Protection $130 \mathrm{~S}$. Ct. 2592 (2010).

18 See Stop the Beach Renourishment 130 S. Ct. 2610-13 \& n 11-12.

19 Stop the Beach Renourishment 130 S. Ct. 2610-13. 
losing the right to accretions, ${ }^{21}$ a right that for hundreds of years has been considered a vested right. ${ }^{22}$ The problem at issue may have best been described by a Florida court in 1965: ${ }^{23}$

Florida is bordered by water on the east, south and west. The numerous islands or keys are constantly changing by various methods of accretion, alluvion, erosion, reliction and avulsion, giving rise to myriad problems. Public policy demands a definite standard of quieting title to these areas.

Public policy also demands that the right to accretions continue to be categorised as a vested right that cannot be arbitrarily taken without the occurrence of a justifying avulsive event or the government paying just compensation.

This note analyses the United States Supreme Court's decision in Stop the Beach Renourishment, Inc. $v$ Florida Department of Environmental Protection. This note focuses on whether the Beach and Shore Preservation Act constitutes an unconstitutional taking of littoral owners' right to accretions through authorisation of beach restoration projects. ${ }^{24}$ Part II of this note provides background information on littoral rights, the Beach and Shore Preservation Act, and the Court's decision in Stop the Beach Renourishment, Inc. $v$ Florida Department of Environmental Protection.

Part III analyses the Court's decision and concludes with a finding that the Beach and Shore Preservation Act constitutes an unconstitutional taking of littoral owners' vested right to accretions. After a careful analysis of the three main cases relied on in the Court's decision, the real background principles of Florida property law come to light; the state does not have a right to fill sovereign submerged lands adjacent to littoral property it does not own, and littoral property owners have a vested right to accretions. This vested right to accretions is found not only in common law but in the Florida Constitution and in Florida Statutes. By setting a fixed erosion control line as the boundary between private and sovereign lands, the Act unconstitutionally eliminates the littoral owners' vested right to accretions without the occurrence of a justifying avulsive event.

The purpose of this article is to stress that the Florida Supreme Court and the United States Supreme Court severely misinterpreted

20 Bureau of Beaches and Coastal Systems, 'Critically Eroded Beaches in Florida' (June 2011) 12, available at http://www.dep.state.fl.us/beaches/publications/ pdf/CritEroRpt7-11.pdf.

See part 2.2 below.

See part 2.1 below.

Ford v Turner 142 So. 2d 335342 (Fla. Dist. Ct. App. 1962).

Notwithstanding its unanimous decision to uphold the Beach and Shore Preservation Act, the Court was otherwise highly fractured. See Stop the Beach Renourishment $130 \mathrm{~S}$. Ct. 2597. A majority of the Court's analysis focuses on what test applies to judicial takings and whether the Florida Supreme Court's decision effected a judicial taking. See Stop the Beach Renourishment $130 \mathrm{~S}$. Ct. 2592. 
Florida property law. I am compelled, based on my conclusions regarding the underlying property law, to state that the Supreme Court should have resolved the judicial takings issue. My interest, however, is in water law and showing that two important courts made a fundamental mistake in categorising the underlying property law. Judicial takings are an issue in this case, but many other scholars have discussed $i^{25}$ and I reserve the issue for another day.

\section{Background}

\subsection{Littoral rights}

[L]ittoral rights are legal rights and, for constitutional purposes, the common law rights of ... littoral owners constitute property. ${ }^{26}$ Although they may be regulated, littoral rights 'may not be taken without just compensation and due process of law. ${ }^{27}$

Such rights include, among other things, "the right to use the water shared by the public,' and

the following vested rights: (1) the right of access to the water, including the right to have the property's contact with the water remain intact; (2) the right to use the water for navigational purposes; (3) the right to an unobstructed view of the water; and (4) the right to receive accretions and relictions to the property. ${ }^{28}$

These rights are in addition to traditional property rights such as the right to possess, use, and dispose. ${ }^{29}$

The littoral owner's common law right to accretions is deeply rooted in American and English law. ${ }^{30}$ Blackstone set forth the common law rule and rationale for the doctrine of accretion (alluvion) and avulsion:

And as to lands gained from the sea, either by alluvion, by the washing up of land and earth, so as in time to make terra firma, or by

See eg $M$ Blumm \& E Dawson 'The Florida beach case and the road to judicial takings' (2011) 35 William \& Mary Environmental Law \& Policy Review 713; DB Barros 'The complexities of judicial takings' (2011) 45 University of Richmond Law Review 903; T Mulvaney 'The new judicial takings construct' (2011) 120 Yale Law Journal Online 247; RT Thomas 'Of woodchucks and prune yards: a view of judicial takings from the trenches’ (2010) 35 Vermont Law Review 437 437-39. Bd. of Trs. of the Internal Improvement Tr. Fund $v$ Sand Key Assocs., Ltd., 512 So. 2d 934936 (Fla. 1987) (citing Hayes v Bowman 91 So. 2d 795 (Fla. 1957); Brickell v Trammell 82 So. 221 (Fla. 1919); Thiesen v Gulf, Fla. \& Ala. Ry. Co., 78 So. 491 (Fla. 1918); Feller v Eau Gallie Yacht Basin, Inc., 397 So. 2d 1155 (Fla. Dist. Ct. App. 1981)).

27 Brickell 82 So. 227

28 Sand Key 512 So. 2d 936 (citing Hughes v Washington 389 US 290 (1967); St. Clair Cnty. v Lovingston 90 US (23 Wall.) 46 (1874); Bowman 91 So. 2d 795; Brickell 82 So. 221; Thiesen 78 So. 491) (emphasis added).

29 See Loretto $v$ Teleprompter Manhattan CATV Corp., 458 US 419 435-36 (1982).

30 See text accompanying $n$ 31-36 below. 
dereliction, as when the sea shrinks below the usual water-marks; in these cases the law is held to be that if the gain be by little and little, by small and imperceptible degrees, it shall go to the owner of the land adjoining. For de minimis non curat lex; and besides, these owners being often losers by the breaking in of the sea, or at charges to keep it out, this possible gain is, therefore, a reciprocal consideration for such possible charge or loss. But if the alluvion be sudden or considerable, in this case it belongs to the king; for, as the king is lord of the sea, and so owner of the soil while it is covered with water, it is but reasonable he should have the soil when the water has left it dry. ${ }^{31}$

The common law rule of accretion set forth by Blackstone has gone without significant change and has been adopted by the United States Supreme Court. ${ }^{32}$ The Court has continually reaffirmed in '[a] long and unbroken line of decisions' that littoral owners have a vested right to accretions. ${ }^{33}$ In 1865, Supreme Court Chief Justice Taney stated that

[a]most all jurists ... both ancient and modern, have agreed that the owner of the land ... bounded [by the sea], is entitled to these additions. ${ }^{34}$

Florida has also adopted the common law rule that littoral owners have a vested right to accretions. ${ }^{35}$ In doing so, Florida courts have adopted four rationale behind the doctrine of accretion:

(1) De minimis non curat lex; (2) he who sustains the burden of losses and of repairs imposed by the contiguity of waters ought to receive whatever benefits they may bring by accretion; (3) it is in the interest of the community that all land have an owner and, for convenience, the riparian is the chosen one; (4) the necessity for preserving the riparian right of access to the water. ${ }^{36}$

Florida's rationale are derived from Blackstone's and have also gone without significant change since Blackstone set forth the rule. ${ }^{37}$

312 W Blackstone Commentaries (1766) 261-62.

32 Hughes 389 US 293-94; Lovingston 90 US (23 Wall.) 68-69; Banks v Ogden 69 US (2 Wall.) 5767 (1864)

33 Hughes 389 US 293-94 ("A long and unbroken line of decisions of this Court establishes that the grantee of land bounded by a body of navigable water acquires a right to any natural and gradual accretion formed along the shore.'); accord Lovingston 90 US (23 Wall.) 68-69 ([The littoral owner's right to accretions] is an inherent and essential attribute of the original property. The title to the increment rests in the law of nature. It is the same with that of the owner of a tree to its fruits, and of the owner of flocks and herds, to their natural increase. The right is a natural, not a civil one.). Banks 69 US 67.

35 See Bd. of Trs. of the Internal Improvement Tr. Fund v Sand Key Assocs., Ltd., 512 So. 2d 934936 (Fla. 1987); see also State v Fla. Nat'l Props., Inc., 338 So. 2d 13 18 (Fla. 1976); Ford v Turner 142 So. 2d 335340 (Fla. Dist. Ct. App. 1962); Mex. Beach Corp. v St. Joe Paper Co., 97 So. 2d 708710 (Fla. Dist. Ct. App. 1957).

36 Bd. of Trs. of the Internal Improvement Tr. Fund v Medeira Beach Nominee, Inc. 272 So. 2d 209 212-13 (Fla. Dist. Ct. App. 1973) (citing Lovingston 90 US (23 Wall.) 67).

37 Compare Lovingston 90 US (23 Wall.) 67-68, and Medeira Beach 272 So. 2d 212-13 with Blackstone (n 31 above) 261-62. 
Courts have noted two significant exceptions to the general principle that littoral owners are entitled to additions of land caused by accretions: (1) 'accretion does not belong to the riparian owner where the riparian himself causes the accretion;' 38 and (2) according to common law, in the case of an avulsive event, the boundary line between sovereign and private property remains unchanged. ${ }^{39}$ If neither exception applies, the '[t]itle to accreted lands ... vests in the riparian owners of abutting lands. 40

\section{Avulsion is the opposite of accretion; ${ }^{41}$}

it is the sudden or perceptible loss of or addition to land by the action of the water or a sudden change in the bed of a lake or the course of a stream. 42

With an avulsive event, the boundary between sovereign submerged lands and private littoral lands normally remains unchanged as the mean high-water line. ${ }^{43}$ This is true regardless of whether the avulsive event exposes previously submerged lands or submerges previous exposed lands. ${ }^{44}$ After an avulsive event, the affected owner is afforded a reasonable time to reclaim the land lost as a result of the avulsive event. ${ }^{45}$

\subsubsection{The Beach and Shore Preservation Act}

In 1961, Florida's Legislature enacted the Beach and Shore Preservation Act. ${ }^{46}$ The Legislature declared it a 'necessary governmental responsibility to properly manage and protect Florida

38 Medeira Beach 272 So. 2d 212 (citing Brundage v Knox 279 Ill. 450 (Ill. 1917); State v Sause 217 Or. 52 (Or. 1959)); accord Sand Key 512 So. 2d 938. In such cases, title to the accreted lands remains with the owner of the previously submerged soi - usually the government. Medeira Beach 272 So. $2 d 212$. The Maderia Beach court noted that: land below the ordinary high water mark is sovereignty land of the state, [and] to permit the riparian owner to cause accretion himself would be tantamount to allowing him to take state land.

As shown in Medeira Beach, the upland owner is entitled to artificial accretions when the owner of the submerged land causes the accretions. Medeira Beach 272 So. $2 d$ 211-12 214-15. The court explained that '[w]ere the state to gain title to this accreted land we believe that riparian titles around the state would be in jeopardy of unmarketability.' Medeira Beach 272 So. 2d 213.

39 See Sand Key 512 So. $2 d 937$.

40 Medeira Beach 272 So. 2d 211-12 (citing Brickell v Trammell 82 So. 221 (Fla. 1919); Mex. Beach Corp., 97 So. 2d 710).

41 Lovingston 90 US (23 Wall.) 68.

42 Sand Key 512 So. 2 d 936.

43 See Sand Key 512 So. 2d 937; see also Bryant v Peppe 238 So. 2d 836 838-39 (Fla. 1970).

44 Sand Key 512 So. 2d 937; see also Bryant 238 So. 2d 838-39.

45 See State v Fla. Nat'l Props., Inc., 338 So. 2d 13 16-18 (Fla. 1976); see also 1 HP Farnham 'The law of waters and water rights' (1904) $\$ 74$ ('If a portion of the land of the riparian owner is suddenly engulfed, and the former boundary can be determined or the land reclaimed within a reasonable time, he does not lose his title to it.'); contra City of Chicago v Ward 169 Ill. 392 (Ill. 1897). 
beaches' because 'beach erosion is a serious menace to the economy and general welfare of the people of [Florida] ... and has advanced to emergency proportions. ${ }^{47}$ The Act establishes procedures for beach restoration 48 and beach nourishment ${ }^{49}$ of 'critically eroded shoreline. ${ }^{50}$ It gives the Department of Environmental Protection the authority to determine which beaches are critically eroded and to 'authorise appropriations to pay up to 75 percent of the actual costs for restoring and nourishing' such beaches. ${ }^{51}$ Local governments apply for funding and must establish a 'mean high water [line] for the area to be restored. 52

Once a beach restoration or nourishment project is determined to be undertaken, a survey of the shoreline is conducted to establish an erosion control line ('ECL'). ${ }^{53}$ In establishing an ECL, the Board of Trustees of the Internal Improvement Trust Fund (the 'Board') 54 is 'guided by the existing line of mean high water.' 55 The Board should consider

the requirements of proper engineering in the beach restoration project, the extent to which erosion or avulsion has occurred, and the need to protect existing ownership of as much upland as is reasonably possible. ${ }^{56}$

Even so, the Board has the authority to set the ECL landward, seaward, or on the mean high-water line. ${ }^{57}$ Once set, the Board records the ECL in the county real property records, 58 and the fixed $E C L$ replaces the mean high-water line as the boundary between sovereign and private lands. ${ }^{59}$ The upland property owner 'continue[s] to be entitled to all common-law riparian rights;' 60 however, the Act eliminates the upland owner's common law right to

47 Fla. Stat. § 161.088 (2010).

48 "Beach restoration" means the placement of sand on an eroded beach for the purposes of restoring it as a recreational beach and providing storm protection for upland properties.' Fla. Stat. § 161.021 (2010).

"Beach nourishment" means the maintenance of a restored beach by the replacement of sand.' Fla. Stat. § 161.021(3) (2010).

50 Fla. Stat. § 161.088 (2010) ('[S]uch beach restoration and nourishment projects ... must be in an area designated as critically eroded shoreline, or benefit an adjacent critically eroded shoreline ...').

51 Fla. Stat. § 161.101(1) (2010)

52 Fla. Stat. §§ 161.101(1), 161.141 (2010).

53 Fla. Stat. § 161.161(3)-(5) (2010).

54 'Board of trustees' is defined as 'the Board of Trustees of the Internal Improvement Trust Fund.' Fla. Stat. § 161.021(5) (2010).

Fla. Stat. § 161.161(5) (2010).

Fla. Stat. \$ $161.161(5)(2010)$

See Fla. Stat. § 161.161(5) (2010).

Fla. Stat. § $161.181(2010)$.

See Fla. Stat. § 161.191 (2010).

Fla. Stat. § 161.201 (2010). Additionally, 'the state shall not allow any structure to be erected upon lands created ... seaward of any erosion control line.' Fla. Stat. § 161.201 (2010). 
accretions. ${ }^{61}$ The ECL can be cancelled if the 'governmental agency charged with the responsibility of maintaining the protected beach fails to maintain the same and as a result thereof the shoreline gradually recedes to a point or points landward of the erosion control line. ${ }^{\prime 62}$

If an authorised beach restoration, beach nourishment, and erosion control project cannot reasonably be accomplished without the taking of private property, the taking must be made by the requesting authority by eminent domain proceedings. ${ }^{63}$

Additionally, when the government conducts restoration and nourishment activities on sovereign submerged lands that would 'unreasonably infringe on riparian rights,' the government must show '[s]atisfactory evidence of sufficient upland interest' adjacent to the riparian land. 64

\subsubsection{Stop the Beach Renourishment, Inc. $v$ Florida Department of Environmental Protection}

In July 2003 after a series of hurricanes, the city of Destin and Walton County, Florida, applied for a permit to use sovereign submerged lands in a project to restore beaches that had been designated 'critically eroded' by the Florida Department of Environmental Protection. ${ }^{65}$ The project proposed to restore 6.9 miles of beach by dredging sand and adding approximately ' 75 feet of dry sand seaward of the mean high-water line.' 66 A coastline survey was completed to determine the mean high-water line, and the Board set an erosion control line on the mean high-water line. ${ }^{67}$ 'Pursuant to section 161.191(1) of the Beach and Shore Preservation Act, this ECL became the boundary between publicly owned land and privately owned upland after it was recorded. ${ }^{, 68}$

'Stop the Beach Renourishment, Inc.', ('Petitioner') - a nonprofit corporation formed by six owners of beachfront property bordering the project area-challenged the project. ${ }^{69}$ In June 2005, after an

61 increase or decrease the proportions of any upland property lying landward of such line, either by accretion or erosion or by any other natural or artificial process.').

62 Fla. Stat. § 161.211 (2010).

63 Fla. Stat. § $161.141(2010)$.

64 Fla. Admin. Code r. 18-21.004(3)(a), (b) (2010).

65 Save Our Beaches, Inc. v Fla. Dep't of Envtl. Prot., 27 So. $3 d 4850$ (Fla. Dist. Ct. App. 2006); Walton Cnty. $v$ Stop the Beach Renourishment, Inc., 998 So. 2d 1102 1106 (Fla. 2008).

66 Stop the Beach Renourishment, Inc. v Fla. Dep't of Envtl. Prot., 130 S. Ct. 2592 2594 (2010).

67 Walton Cnty. 998 So. 2d 1106; Save Our Beaches 27 So. 3d 59.

68 Walton Cnty., 998 So. 2 d 1106.

69 Walton Cnty., 998 So. 2d 1106. Each of the six members owned property to the mean high-water line. Save Our Beaches 27 So. 3d 59. 
unsuccessful administrative challenge by Petitioner, the Department issued a permit authorising use of sovereign submerged lands for the project. ${ }^{70}$ Petitioner subsequently brought suit, and the First District Court of Appeal of Florida determined the Act unconstitutionally eliminated Petitioner's littoral 'rights to (i) receive accretions and relictions to the property, and (ii) have the property's contact with the water remain intact. 71 The district court also certified to the Supreme Court of Florida the following question, as rephrased by the Florida Supreme Court: 'On its face, does the Beach and Shore Preservation Act unconstitutionally deprive upland owners of littoral rights without just compensation?"72

The Florida Supreme Court answered the question in the negative ${ }^{73}$ and held that the doctrine of avulsion permitted the State to restore beaches and set a fixed boundary line between sovereign and private lands. ${ }^{74}$ The court also described the right to accretions as a future contingent interest not implicated by the Act and held there is no littoral right to contact the water. ${ }^{75}$ The Petitioner's request for rehearing was denied ${ }^{76}$ and the United States Supreme Court granted certiorari. ${ }^{77}$

In an otherwise highly fractioned opinion that focused on judicial takings, ${ }^{78}$ a unanimous Court upheld the Beach and Shore Preservation Act as facially constitutional in a Fifth Amendment takings challenge. ${ }^{79}$ The Court determined that the background principles of Florida property law

allowed the State to fill in its own seabed, and the resulting sudden exposure of previously submerged land was treated like an avulsion for purposes of ownership. The right to accretions was therefore subordinate to the State's right to fill. ${ }^{80}$

Save Our Beaches 27 So. 3d 51.

Save Our Beaches 27 So. 3d 57-58.

Walton Cnty., 998 So. 2d 1105 (footnotes omitted).

Walton Cnty., 998 So. 2d 1105.

Walton Cnty., 998 So. 2d 1116-18.

Walton Cnty., 998 So. 2d 1118-20.

Walton Cnty., 998 So. 2d 1102.

Stop the Beach Renourishment, Inc. v Florida Dept. of Environmental Protection 130 S. Ct. 2592 (2010).

78 Stop the Beach Renourishment 130 S. Ct. 25922597.

79 See Stop the Beach Renourishment $130 \mathrm{~S}$. Ct. 2610-13 \& $\mathrm{n} 11-12$. The majority of the Court's opinion focuses on the appropriate test for judicial takings and whether, by upholding the beach restoration act, the Florida Supreme Court effectuated a judicial taking of Petitioner's right to accretions and to contact with the water. See Stop the Beach Renourishment, 130 S. Ct. 2592. 


\section{Analysis}

\subsection{The state of Florida does not have the right to fill sovereign submerged lands adjacent to littoral property it does not own}

In discussing the background principles of Florida property law, the United States Supreme Court improperly relies on three cases to establish that the right to accretions is subordinate to the state's right to fill. ${ }^{81}$ A close evaluation of these cases indicates that the State of Florida does not have the right to fill sovereign submerged lands adjacent to littoral property it does not own. Each case will be discussed in turn.

\subsubsection{Hayes $v$ Bowman}

The United States Supreme Court cites Hayes $v$ Bowman ${ }^{82}$ for the proposition that the state has the right to fill; 83 however, the right to fill was not at issue in that case. ${ }^{84}$ Bowman was about the right to an unobstructed view of the water, and the court in that case set forth a specific rule addressing the right to view. ${ }^{85}$ Bowman does provide a general rule about the right to fill; upland owners can fill submerged land abutting their property when they have title to such land and are authorised by statute to fill such land. ${ }^{86}$

In Bowman, both the appellant and appellee owned littoral property on the 'Channel of the Bay' such that their boundary lines did not run perpendicular to either the channel cut or the shore. ${ }^{87}$ The appellees acquired submerged land adjacent to their property from the Trustees of the Internal Improvement Fund and proposed to fill such land. ${ }^{88}$ The dispute concerned what area littoral owners were entitled to view based on their boundary lines in relation to the shore

81 the Beach Renourishment 130 S. Ct. 2611 (citing Hayes $v$ Bowman 91 So. $2 \mathrm{~d}$ 795 799-800 (Fla. 1957); State ex rel. Buford v City of Tampa 102 So. 336341 (Fla. 1924); Thiesen v Gulf, Fla. \& Ala. Ry. Co., 78 So. 491 501-03 507 (Fla. 1918)).

82 Hayes $v$ Bowman 91 So. 2d 795 (Fla. 1957).

83 Stop the Beach Renourishment $130 \mathrm{~S}$. Ct. 2611 (citing Bowman 91 So. 2d 799-800).

84 See Bowman 91 So. 2 d 801.

85 See Bowman 91 So. $2 \mathrm{~d} 801$.

86 See Bowman 91 So. 2d 797-802.

87 Bowman 91 So. 2 d 798.

88 Bowman 91 So. $2 \mathrm{~d} 800$. 'The submerged lands acquired by appellees for purposes of the proposed fill were purchased under' chapter 26776, Florida Statutes section 253.12 (1951). Bowman 91 So. 2d 800. Under that section, 'title to all sovereignty lands (except in Dade and Palm Beach counties) was vested in the Trustees of the Internal Improvement Fund with power of disposition thereof in the manner provided by the statute.'

Today, Florida Statutes section 253.12 permits the Board of Trustees of the 
and channel cut. ${ }^{89}$ The court recognised the right to 'a direct, unobstructed view of the Channel' and prescribed a rule preserving that right. 90

Not only was the dispute over the right to view and not the right to fill, ${ }^{91}$ but under Florida Statutes chapter 271 (more commonly known as the Butler Bill), littoral owners already had a statutory right to fill submerged lands adjacent to their property. ${ }^{92}$ For Bowman or any case to properly support the Supreme Court's position, the state would have to fill, or convey the right to fill, to a private party having no relation to the littoral uplands. In Bowman, the state conveyed the right to fill to a private party; however, the private party owned the adjacent upland property and only received the right to fill land adjacent to that property. ${ }^{93}$ Therefore, the state did not convey the right to a party without an upland interest or having no relation to the land. Since no third party was involved and the upland owner already had the right to fill, the conveyance did not infringe on the littoral rights of any third party.

Bowman cannot support the proposition that the state has the right to fill because the state did not convey the right to a party without an upland interest or having no relation to the land. In Bowman, the upland owner purchased the submerged lands adjacent to his property and he was authorised by statute to fill such land. ${ }^{94}$ Since no third party was implicated, Bowman stands for the general rule that littoral owners can fill submerged lands abutting their littoral property when they have title to such lands and are authorised

Internal Improvement Trust Fund to sell and convey 'sovereignty tidal and submerged bottom lands;' Fla. Stat. § 253.12(1) (2010); however, when objections are filed, the Board cannot '[i]nterfere with the lawful rights granted riparian owners.' Fla. Stat. § 253.12 (4)(b) (2010). Additionally, the Board can only sell sovereign lands 'lying between the ordinary mean high-water line and any bulkhead line' to 'the upland riparian owner and to no other person, firm, or corporation.' Fla. Stat. § 253.12(4)(e) (2010).

89 Bowman 91 So. $2 \mathrm{~d} 801$ (Appellants claim that they are entitled to an unobstructed view toward the Channel over a corridor measured by extending their northeasterly-southwesterly lot lines directly to the Channel. Appellees claim that this corridor is to be bounded by imaginary lines drawn at right angles from the thread of the Channel to the corners of appellants' lot.).

90 Bowman 91 So. 2d 802 (recognising a right to view 'over an area 'as near as practicable' in the direction of the Channel so as to distribute equitably the submerged lands between the upland and the Channel[, considering] ... the lay of the upland shore line, the direction of the Channel and the co-relative rights of adjoining upland owners').

91 The parties in Bowman both owned lots in a subdivision that was built by dredging and filling in the seabed; Bowman 91 So. 2d 797-98; therefore, it is unlikely that either party thought the right to fill was at issue.

92 Bowman 91 So. 2d 800. The Butler Bill, Fla. Stat. ch. 8537 (1921), provisionally granted littoral owners whose lands extended to the high-water mark, the right to 'dredge, bulkhead, and fill in front of his land to the edge of the channel.' Bowman 91 So. 2d 800; see also RH Hunt 'Riparian rights in Florida' (1955) 8 University of Florida Law Review 393393 398-99.

93 Bowman 91 So. 2d 800.

94 Bowman 91 So. 2d 797-802. 
by statute to fill such lands. ${ }^{95}$ Additionally, when the state owns submerged lands it can convey such lands to the upland property owner. 96

\subsubsection{State ex rel. Buford $v$ City of Tampa}

The Court also cites State ex rel. Buford $v$ City of Tampa ${ }^{97}$ for the proposition that the state has the right to fill. ${ }^{98}$ In Buford, the City of Tampa contracted to sell a significant section of submerged lands to D.P. Davis, a private citizen. ${ }^{99}$ The Florida Attorney General challenged the contract and sought to have Davis and the City of Tampa enjoined from carrying out the contract. 100

The Buford court first noted that the Florida state constitution did not forbid the Legislature from conveying sovereign submerged lands lying between the high and low water mark. ${ }^{101}$ The court then determined that the Act of 1921, chapter 8537 - the Butler Bill, which was also at issue in Bowman - was controlling. ${ }^{102}$ The Butler Bill declared: 'It is for the benefit of the State of Florida that water front property be improved and developed.'103 To promote such development, the act vested littoral owners with title to submerged lands adjacent to their littoral property. ${ }^{104}$ The act also provided such owners with, among other things, the right to 'fill up from the shore, bank or beach as far as may be desired, not obstructing the channel.' 105

Even though the City of Tampa contracted to convey sovereign submerged lands to a private party, it did not convey land, or the right to fill land, adjacent to any third party. ${ }^{106}$ This is because Davis and the City of Tampa owned all of the land adjacent to the submerged lands being conveyed, and thus, already had the right to fill such land. ${ }^{107}$ Under the Butler Bill, the City of Tampa - as a littoral owner - had the right to fill submerged lands adjacent to uplands it owned. ${ }^{108}$ Likewise, Davis had the right to fill submerged lands adjacent to his property. ${ }^{109}$ No third parties owned land adjacent to

Bowman 91 So. 2d 797-802.

Bowman 91 So. 2d 797-802.

State ex rel. Buford v City of Tampa 102 So. 336 (Fla. 1924).

Stop the Beach Renourishment, Inc. $v$ Florida Dept. of Environmental Protection 130 S. Ct. 25922611 (2010).

99 Buford 102 So. 339.

100 Buford 102 So. 339.

101 Buford 102 So. 340.

102 Buford 102 So. 340-41.

103 Act of 1921, Fla. Stat. ch. 8537 (1921); Buford 102 So. 338.

104 Buford 102 So. 341.

105 Buford 102 So. 341.

106 See Buford 102 So. 339341.

107 See Buford 102 So. 339341.

108 See Buford 102 So. 339341.

109 See Buford 102 So. 339341. 
the area being filled and the upland owners were granted the right to fill by statute; therefore, Buford cannot be cited for the proposition that the state has the right to fill sovereign submerged lands. Rather, Buford provides that a private citizen and the state - as littoral property owners - can fill submerged lands abutting their property when authorised by statute. ${ }^{110}$ Additionally, when the state owns submerged lands and the adjacent uplands, it can convey the submerged lands to a private citizen as long as it complies with any constitutional or statutory limitations. ${ }^{111}$

This conclusion is consistent with Bowman and the prevailing law at the time because the Butler Bill provided only the upland owner with the right to fill and the right only applied to submerged lands adjacent to their littoral property. ${ }^{112}$ This is also consistent with Florida law today because the Butler Bill was repealed in 1971 and upland owners no longer have a vested right to fill the seabed adjacent to their property. ${ }^{113}$ Without the Butler Bill, the City of Tampa and DP Davis - as littoral owners - would not have had the right to fill, and thus, would not have been protected by the rule set forth in State ex rel. Buford $v$ City of Tampa.

\subsubsection{Thiesen v Gulf, Florida \& Alabama Railroad Co.}

The Supreme Court cites to Thiesen $v$ Gulf, Florida \& Alabama Railroad Co. ${ }^{114}$ for the proposition that the right to accretions is subordinate to the state's right to fill. ${ }^{115}$ This conclusion is especially troubling considering the Thiesen court went out of its way-after stating the right to fill was not at issue-to indicate that the State of Florida does not have the right to fill submerged land adjacent to uplands it does not own. ${ }^{116} \mathrm{~A}$ careful analysis of Thiesen provides a general rule that the state must pay just compensation for taking an upland owner's littoral rights when the state fills the seabed adjacent to upland property it does not own. ${ }^{117}$

Thiesen involved a littoral property owner's claim that a railroad's state-authorised filling of submerged lands adjacent to his

110 See Buford 102 So. 339341.

111 See Buford 102 So. 339341.

112 See Hunt (n 91 above) 393 398-99.

113 See Fla. Stat. ch. 71-355, § 77 (1971); Fla. Stat. ch. 57-362, § 9 (1957); see also Fla. Admin. Code r. 18-21.004, 21.013 (2009); Office of Submerged Lands and Environmental Resources 'Do i need a permit?' http://www.dep.state.fl.us/ water/wetlands/ (providing permit applications for, among other things, 'construction activity that would affect wetlands, alter surface water flows, or contribute to water pollution' and 'any construction on or use of submerged lands owned by the State') (accessed 25 January 2011).

114 Thiesen v Gulf, Florida \& Alabama Railroad Co., 78 So. 491 (Fla. 1918).

115 See Stop the Beach Renourishment, Inc. v Fla. Dep't of Envtl. Prot., $130 \mathrm{~S} . \mathrm{Ct}$. 25922611 (2010).

116 Thiesen 78 So. 507

117 Thiesen 78 So. 507. 
littoral property and the construction of a railroad upon the filled land interfered with his rights to access and to wharf out to a shipping channel. ${ }^{118}$ The Thiesen court determined that the plaintiff did not have the right to construct wharves, piers, and docks, or the right to fill under the Act of 1856 because his property did not extend to the low water mark. ${ }^{119}$

Even though the littoral owner did not have a right to fill, the court determined the state did not have the ability to convey a right to fill to a third party. ${ }^{120}$ Chapter 4802, Laws of Florida 1899 purported to grant land to the City of Pensacola, and the city granted a portion of such land to the railroad. ${ }^{121}$ The court found that ' $[\mathrm{t}] \mathrm{his}$ act undertakes to deprive without compensation' the common law rights of littoral owners, ${ }^{122}$ rights which constitute property that cannot be deprived without just compensation"123 and 'cannot be arbitrarily or capriciously destroyed or impaired.'124 The court acknowledged that the state's right to fill was not at issue; however, the court implied that the state did not have the right to fill the seabed adjacent to private littoral property unless it paid just compensation for injury to the littoral landowner. ${ }^{125}$

The Thiesen court determined that the state-authorised filling of submerged land and a railroad's construction of tracks thereon

Thiesen 78 So. $500-01$

Thiesen 78 So. 501 503. Upon adoption in 1921, the Butler Bill - which was at issue in both Buford and Bowman - was made retroactive, so as to take effect from December 27, 1856, and was intended to enlarge the act of that year entitled: 'An Act to Benefit Commerce.' State ex rel. Buford v City of Tampa 102 So. 336338 (Fla. 1924).

The elements of the Butler Bill discussed above; see text accompanying notes 101-04 above; were all included in the 1856 Act to Benefit Commerce, which was at issue in Theisen. Thiesen 78 So. 491 . The 1856 act proclaimed that 'it is for the benefit of commerce that wharves be built and wharehouses erected.' Thiesen 78 So. 492. The act vested littoral owners with title to submerged lands adjacent to their littoral property, and included, among other things, the right to 'fill up from the shore, bank or beach as far as may be desired, not obstructing the channel.' Thiesen 78 So. 492. The 1856 Act required littoral owners to own land extending to the low-water mark; Thiesen 78 So. 492; and the Butler Bill only required littoral owners to own land extending to the high-water mark. Buford 102 So. 338. The land-owner in Thiesen held littoral property under the common law rule because his land extended to the high water mark; however, the owner was not entitled to rights under the Act of 1856 because his land did not extend to the low water mark. See Thiesen 78 So. 493. Under the Butler Bill, the littoral landowner in Thiesen would have also had the right to fill. See Buford 102 So. 338; see also Hayes $v$ Bowman 91 So. 2d 795800 (Fla. 1957).

121 Thiesen 78 So. $506-07$.

122 Thiesen 78 So. $505-06$.

122 Thiesen 78 So. 506.

123 Thiesen 78 So. 506. (citing Broward v Mabry 50 So. 826 (Fla. 1909)).

124 Thiesen 78 So. 507 (citing Yates v City of Milwaukee 77 US (10 Wall.) 497 (1870)).

125 Thiesen 78 So. 507 (We do not appreciate the force of the argument that the state as owner of the submerged land between high and low water mark should not, in the event it desires to improve the water front for navigation, be required to pay to the owner of the upland a just compensation for injury to his property incident to such public enterprise.). 
deprived the upland owner of his littoral rights, and the railroad would be required to pay just compensation. $\$ 26$ The court reasoned that such rights often constitute a property's 'chief value and desirability.' 127 The United States Supreme Court in Stop the Beach Renourishment, erroneously suggests the Thiesen court limited compensation to the right of access. ${ }^{128}$ The court in Thiesen did not specify that only the right to access required compensation. ${ }^{129}$ By stating that the owner was deprived of his 'rights as a riparian owner,' the court implied that all riparian rights were deprived and required compensation. ${ }^{130}$ In defining riparian rights, the court included, among other things, the right to accretions, an unobstructed view over the waters, and right of navigation, bathing, and fishing. ${ }^{131}$ If Thiesen stands for the proposition - as the Supreme Court suggests that the state, as owner of the submerged land between the high and low water marks, can fill the seabed, then it stands for the proposition that doing so requires the state to pay just compensation. ${ }^{132}$ As the court reasoned, filling the seabed 'destroys a large part of the value of plaintiff's property, perhaps by wholly depriving him of his rights as a riparian owner.

Thiesen is consistent with Florida law today because the State of Florida does not have a general right to fill. ${ }^{134}$ Florida law prohibits 'any state agency or county, city, or other political subdivision' from filling the seabed 'for a municipal, county, state, or other public purpose unless such agency is the riparian upland owner or holds the consent in writing of the riparian upland owner."135 Additionally, more recent lower court decisions such as Kendry $v$ State Road Department ${ }^{136}$ have held that the state does not have the right to fill sovereign submerged lands adjacent to littoral property it does not own. ${ }^{137}$

A close analysis of Buford, Bowman, Thiesen, and the repeal of the Butler Bill, all indicate that the United States Supreme Court

126 Thiesen 78 So. 507 .

127 Thiesen 78 So. 507

128 Stop the Beach Renourishment, Inc. v Fla. Dep't of Envtl. Prot., 130 S. Ct. 2592 2611 (2010).

129 See Thiesen 78 So. 491501503.

130 See Thiesen 78 So. 491501503.

131 Thiesen 78 So. 507

132 Thiesen 78 So. 507.

133 Thiesen 78 So. 507.

134 See Fla. Stat. \$ 253.12(5)(b) (2010).

135 Fla. Stat. \$ 253.12(5)(b) (2010). Florida Statutes section 253.12(5)(b) does not apply to situations where the Board establishes an erosion control line and authorises a beach restoration project; even so, such an extensive limitation on the state's ability to fill sovereign submerged land supports the statement that the state does not have a general right to fill. Fla. Stat. $\S 253.12(5)(\mathrm{b})(2010)$. Kendry v State Road Department 213 So. 2d 23 (Fla. Dist. Ct. App. 1968).

137 Kendry 213 So. 2d 27-28 (stating the state effectuates a taking of an upland owner's riparian rights by filling submerged land adjacent to riparian property of a private citizen and claiming title to the fill). 
erroneously determined that the State of Florida has the right to fill. The State of Florida does not have the right to fill sovereign submerged lands adjacent to littoral property it does not own. ${ }^{\Uparrow 38}$ Likewise, it does not have the ability to convey such a right to a private party that is not the upland owner. While such a finding is not conclusive proof that the Beach and Shore Preservation Act is unconstitutional, it does significantly impact the takings analysis, and thus, will be taken into account in subsequent sections of this note.

\subsection{Littoral owners have a vested right to accretions}

The court below in Walton County $v$ Stop the Beach Renourishment, Inc. ${ }^{139}$ effectuated a major change in Florida property law by categorising the right to accretions as a contingent right. ${ }^{140}$ Prior to that decision, both the United States Supreme Court and Florida Supreme Court continuously categorised the right as a vested right. ${ }^{141}$ Subsequently in Stop the Beach Renourishment, the Supreme Court found it unnecessary to categorise the right as vested or contingent because the takings clause applies in either case. ${ }^{142}$ It is necessary, however, to categorise the right to determine just compensation and to provide certainty to property owners. Maintaining consistency and predictability in littoral rights is vital in a state like Florida, especially since a vested right is more valuable than a contingent future right that may or may not come to fruition.

Littoral property owners in Florida have a vested common law ${ }^{143}$ and statutory right to accretions. ${ }^{144}$ The right is deeply rooted in American, English, and Florida law, and has gone without significant change since Blackstone set forth the rule in $1766 .^{145}$

138 Littoral property owners also do not have a right to fill; a private property owner must first obtain an authorisation to use submerged lands and an environmental resource permit prior to 'any construction activity that would effect wetlands, alter surface water flows, or contribute to water pollution.' See Office of Submerged Lands and Environmental Resources (n 113 above). Walton County $v$ Stop the Beach Renourishment, Inc., 998 So. 2d 11021118 (Fla. 2008).

140 Walton Cnty., 998 So. 2d 1118.

141 See Hughes $v$ Washington 389 US $290293-94$ (1967); Bd. of Trs. of the Internal Improvement Tr. Fund v Sand Key Assocs., Ltd., 512 So. 2d 934936 (Fla. 1987).

142 Stop the Beach Renourishment, Inc. v Fla. Dep't of Envtl. Prot., $130 \mathrm{~S}$. Ct. 2592 2601 (2010).

143 See part 3.2.1 below.

144 See part 3.2.2 below.

145 See part 2.1 above. 


\subsubsection{Common law right to accretions}

In 1976, the Florida Supreme Court determined that a littoral owner's right to accreted land is a 'vested' right that cannot be taken without just compensation and due process of law. ${ }^{146}$ In that case, the State of Florida tried to replace the mean high-water line - the fluctuating boundary between sovereign submerged lands and littoral lands with a fixed boundary. ${ }^{\text {447 }}$ The court held that the state's establishment of a fixed boundary effectuated an unconstitutional taking of private property, including the right to accretions. ${ }^{148}$ In invalidating the statute at issue, the court noted that

[b]oth Federal and Florida courts have held that an owner of land bounded by the ordinary high water mark of navigable water is vested with certain riparian rights, including the right to ... accretion[s]. ${ }^{149}$

Under these background principles of Florida property law, littoral owners have a vested common law right to accretions.

\subsubsection{Statutory right to accretions}

The United States Supreme Court analysed whether the beach restoration project constituted a taking by eliminating 'the right to accretions[] and the right to have littoral property touch the water. ${ }^{151}$ In characterising the right at issue as 'the right to have littoral property touch the water, ${ }^{152}$ the Court overlooked the right to contact the mean high-water line and the right to contact the ordinary high watermark. These rights provide a statutory right to accretions $^{153}$ and do not always guarantee contact with the water. ${ }^{154}$ Co. v Arizona 414 US 313 329-31 (1973); St. Clair Cnty. v Lovingston 90 US (23 Wall.) 46 (1874); Thiesen v Gulf, Fla. \& Ala. Ry. Co., 78 So. 491 (Fla. 1918); Padgett v Cent. \& S. Fla. Flood Control Dist., 178 So. 2d 900 (Fla. Dist. Ct. App. 1965)).

147 State $v$ Fla. Nat'l Props., Inc., 338 So. 2d 17-19.

148 State v Fla. Nat'l Props., Inc., 338 So. $2 d$ 17-18.

149 State v Fla. Nat'l Props., Inc., 338 So. 2d 17 (citing Bonelli 414 US 329-31;

Lovingston 90 US (23 Wall.) 46; Thiesen 78 So. 491; Padgett 178 So. $2 d$ 900).

150 See Bd. of Trs. of the Internal Improvement Tr. Fund v Sand Key Assocs., Ltd., 512 So. 2d 934936 (Fla. 1987); Ford v Turner 142 So. 2d 335340 (Fla. Dist. Ct. App. 1962); Mex. Beach Corp. v St. Joe Paper Co., 97 So. 2d 708710 (Fla. Dist. Ct. App. 1957).

151 See Stop the Beach Renourishment, Inc. v Fla. Dep't of Envtl. Prot., $130 \mathrm{~S}$. Ct. 2592 2610-11 \& $n 11$ (2010).

152 Stop the Beach Renourishment 130 S. Ct. 2610.

153 See text accompanying $n$ 154-61 below.

154 


\section{The right to contact the mean high-water line}

Littoral property owners in Florida have a statutory right to accretions and to contact the mean high-water line. The Florida Constitution provides that '[ $\mathrm{t}]$ he title to lands under navigable waters, within the boundaries of the state, which have not been alienated, including beaches below mean high-water lines, ${ }^{155}$ is held by the state, by virtue of its sovereignty, in trust for all the people. ${ }^{156}$ In other words, the 'mean high-water line' is the boundary between private and sovereign lands on navigable waters, and unless it has been previously alienated, the government owns the land below the mean high-water line. 157

The mean high-water line, as the boundary between private and sovereign lands, is subject to change over time because it is based on a 19 year average height of high waters. ${ }^{158}$ The upland owner gains land as the boundary moves seaward and loses land as the line moves landward. Conversely, the government loses land as the mean highwater line moves seaward and gains land as the line moves landward. This change in ownership as the mean high-water line moves is equivalent to a statutory right to accretions. ${ }^{159}$ Whether the boundary moves because of the gradual and imperceptible addition of soil to the shore of waterfront property or by the addition of land from the gradual and imperceptible withdrawal of a body of water, the Florida Constitution provides upland owners with title to accreted land. ${ }^{160}$ Title remains with the upland owner because the upland owner continues to own land up to and including the mean high-water line, even after a gradual change in the mean high water. ${ }^{161}$ As with the common law doctrine of accretions, where the loss (or addition) of land is sudden and perceptible, the doctrine of avulsion applies and

155 The 'mean high-water line' is 'the intersection of the tidal plane of mean high water with the shore.' Fla. Stat. § 177.27(15) (2010). 'Mean high water' is 'the average height of the high waters over a 19-year period.' Fla. Stat. $\$ 177.27(14)$ (2010). 'For shorter periods of observation, 'mean high water' means the average height of the high waters after corrections are applied to eliminate known variations and to reduce the result to the equivalent of a mean 19-year value.' Fla. Stat. \& 177.27(14) (2010). The 19-year value represents the 'nineteen-year tidal cycle,' which is the 'period of time generally reckoned as constituting a full tidal cycle.' Fla. Stat. § 177.27(21) (2010). The littoral owner owns up to and including the mean high-water line. Sand Key 512 So. 2d 936; State v Fla. Nat'l Props., Inc., 338 So. $2 d 13$ 18-19 (Fla. 1976); Thiesen v Gulf, Fla. \& Ala. Ry. Co., 78 So. 491493 (Fla. 1918).

156 See Fla. Const. art. X, § 11.

157 See Fla. Const. art. X, § 11; Sand Key 512 So. 2d 936; Fla. Nat'l Props., 338 So. 2d 18-19; Thiesen 78 So. 493.

158 See n 155 above.

159 See n 12 above.

160 See Fla. Const. art. X, § 11.

161 See Fla. Const. art. X, § 11. 
the boundary between sovereign submerged lands and private uplands will normally remain unchanged. ${ }^{162}$

\section{Right to contact the ordinary high watermark}

Since December 31, 1985, littoral property owners in Florida have also had a statutory right to contact the 'ordinary high watermark.'163 The right to contact the ordinary high watermark is equivalent to the right to contact the mean high-water line, ${ }^{164}$ which provides a statutory right equivalent to the common law doctrine of accretions. ${ }^{165}$

Prior to 31 December 1985, Florida Statutes section 197.228 provided in part:

Riparian rights are those incident to land bordering upon navigable waters. They are rights of ingress, egress, boating, bathing and fishing and such others as may be or have been defined by law. Such rights are not of a proprietary nature. They are rights inuring to the owner of the riparian land but are not owned by him. They are appurtenant to and are inseparable from the riparian land. The land to which the owner holds title must extend to the ordinary high watermark of the navigable water in order that riparian rights may attach. Conveyance of title to or lease of the riparian land entitles the grantee to the riparian rights running therewith whether or not mentioned in the deed or lease of the upland. ${ }^{166}$

In McDowell $v$ Trustees of Internal Improvement Fund, ${ }^{167}$ the Florida Supreme Court determined that this 'subsection [of the Florida code] was appropriately included in the chapter on taxation, and it was apparently intended by the legislature to provide a guide for the benefit of tax assessors. ${ }^{168}$ Similarly, in 1985 the Florida Supreme Court in Belvedere Development Corporation $v$ Department of Transportation, Division of Administration, ${ }^{169}$ held the same section inapplicable in a property dispute because it was tax law. ${ }^{170}$

The decision in Belvedere came down on 11 July 1985, and rehearing was denied on 4 November 1985. ${ }^{171}$ Effective 31 December 1985, the Florida Legislature renumbered section 197.228 as 253.141 and moved it from the chapter on taxation to the chapter on public

162 See part 2.1 above.

163 See text accompanying n 190-93 below.

164 See text accompanying n 189-95 below.

165 See text accompanying n 154-61 above.

166 Fla. Stat. \$ 197.228 (1983); Belvedere Dev Corp. v Dep't of Transp., Div of Admin., 476 So. 2d 649652 (Fla. 1985).

McDowell $v$ Trustees of Internal Improvement Fund 90 So. 2d 715 (Fla. 1956).

168 McDowell 90 So. 2d 717 (citing Webb v Giddens 82 So. $2 d 743745$ (Fla. 1955)).

169 Belvedere 476 So. 2d 649.

170 Belvedere 476 So. 2d 652-53 (citing Maloney, Plager \& Balwin Water law and administration (1968) § 34.3).

171 Belvedere 476 So. 2d 649. 
lands and property. ${ }^{172}$ No other changes were made to the law on that date, ${ }^{173}$ and the statute remains in effect without any substantive changes. ${ }^{174}$

The sole reason the Belvedere court found section 197.228 inapplicable in a property dispute was its inclusion in the chapter on taxation. ${ }^{175}$ Belvedere was effectively overruled in less than six months when the Florida legislature renumbered section 197.228 and moved it to the public lands and property chapter. ${ }^{176}$

While the definition of 'riparian rights' was renumbered in the Florida code and included in the chapter on public lands and property, there is no legislative history explaining the change and the change has not been well developed in Florida case law. ${ }^{177}$ Cases after 1985 have cited to Florida Statutes section 253.141 for the definition of riparian (or littoral) rights in the context of property disputes; however, application of the definition has been inconsistent. Some courts have applied the definition to private property owners ${ }^{178}$ and others have limited its applicability to public lands. ${ }^{179}$ In either case, the Florida legislature codified some of the rights of riparian land owners $^{180}$ that were previously predominately determined by common law. 181

Fla. Stat. \$ 253.141 (2010). Florida Statutes section 253.141 has remained unchanged since 31 December 1985, with the exception that the sentence ' $[t]$ hey are rights inuring to the owner of the riparian land but are not owned by him' now reads 'him or her.' Compare Fla. Stat. § 253.141 (2010), with Fla. Stat. § 253.141 (1985).

175 See Belvedere 476 So. $2 \mathrm{~d} 652-53$

Fla. Admin. Code r. 18-21.004(3) (2010) (indicating that Florida Statutes section 253.141 defines the 'traditional, common law riparian rights ... of upland property owners adjacent to sovereignty submerged lands').

177 TB Proctor 'Erosion of riparian rights along Florida's coast' (2004) 20 Journal of Land Use \& Environmental Law 117 132-36.

178 See Teat $v$ City of Apalachicola 738 So. 2d 413 413-14 (Fla. Dist. Ct. App. 1999) (" $[A] n$ individual must own property down to the ordinary high water mark in order to possess riparian rights.'); see also Tewksbury $v$ City of Deerfield Beach 763 So. 2d 1071 1071-72 (Fla. Dist. Ct. App. 1999) (applying section 253.141 in a dispute between owners of privately-owned submerged land and owners of the privately-owned adjacent uplands); Haynes v Carbonell 532 So. 2d 746748 (Fla. Dist. Ct. App. 1988).

179 City of Tallahassee v J.R. 771 So. 2d 587588 (Fla. Dist. Ct. App. 2000) ('The City's reliance on the definition of "riparian rights"' found in section 253.141, Florida Statutes (1999), is also misplaced, for that chapter relates to State-owned lands ...').

180 Fla. Admin. Code r. 18-21.004(3) (2010). Even the court in Webb v Giddens noted - prior to the Florida Legislature renumbering Florida Statutes section 197.228 that ' $[\mathrm{w}]$ hile this statute is included in the chapter on Taxation and Finance, ... it may be accepted as a partial codification of the common law on the subject.' Webb v Giddens 82 So. 2d 743745 (Fla. 1955).

181 See Belvedere Dev Corp. $v$ Dep't of Transp., Div of Admin., 476 So. $2 \mathrm{~d} 649$ (Fla. 1985); Hayes $v$ Bowman 91 So. 2d 795 (Fla. 1957); State ex rel. Buford $v$ City of Tampa 102 So. 336 (Fla. 1924); Thiesen v Gulf, Fla. \& Ala. Ry. Co., 78 So. 491 (Fla. 1918). 
If the definition of 'riparian rights' in Florida Statutes section 253.141 only applies to public lands, then presumably the common law definition of riparian rights would still apply to private-property owners. While two separate definitions would not cause a problem in a dispute between two private land-owners, it could cause significant problems in a dispute between the government and a private property-owner. The government and private property owner could have overlapping rights; the private land-owner could be entitled to riparian rights under common law and the government could be entitled to the same rights by statute. To avoid conflicting rights, promote continuity, and increase the marketability of land bordering navigable waters, courts should apply the definition of 'riparian rights,' as found in Florida Statutes section 253.141, to all property. ${ }^{182}$

Assuming arguendo, that the definition of 'riparian rights' in section 253.141 only applies to public lands, it still provides an adequate definition to determine if a taking occurs where the government-as a land owner-is a party to a dispute in which littoral rights are at issue. If the state obtains littoral rights under the statute, then either (1) the private owner has been deprived of such littoral rights, ${ }^{183}$ or (2) the government has littoral rights in common with the private land-owner. ${ }^{184}$ In either case, a taking has occurred because the littoral owner has been deprived of littoral rights ${ }^{185}$ or of exclusive ownership of littoral rights. ${ }^{186}$

In defining riparian rights, Florida Statutes section 253.141 provides that the owner of land 'extend[ing] to the ordinary high watermark of the navigable water' has riparian 'rights of ingress, egress, boating, bathing and fishing and such others as may be or have been defined by law. ${ }^{187}$ It is clear from the statute that the owner of

It is also important to note that in defining 'riparian rights,' section 253.141 uses the pronouns 'him' and 'her' when referring to the land-owner. Fla. Stat. \$ 253.141 (2010). If the definition of riparian rights was only intended to apply to public land, then the pronouns 'him' and 'her' should have been avoided. The pronouns 'him' and 'her' indicate the definition applies to more than the government, which would correctly be referred to as 'it."

183 The government is entitled to littoral rights under Florida Statutes section 253.141 if it acquires the mean high-water line. Fla. Stat. § 253.141 (2010). When the government acquires the mean high-water line, the upland owner ceases to be entitled to littoral rights because the upland property is no longer considered littoral. See $\mathrm{n} 155$ above.

184 See text accompanying n 179-82 above.

185 See eg, Webb's Fabulous Pharmacies, Inc. v Beckwith 449 US 155 163-65 (1980).

186 For example, under Florida Statutes section 253.141, the owner of the mean highwater line is entitled to the rights of ingress and egress. Fla. Stat. § 253.141 (2010). If the government has the rights of ingress and egress, the upland littoral owner has been deprived of the right to exclude others. See eg, Kaiser Aetna $v$ United States 444 US 164176 (1979) (compelling public access would deprive 'the owner ... [of] one of the most essential sticks in the bundle of rights that are commonly characterised as property-the right to exclude others')

Fla. Stat. § 253.141 (2010). 
land extending to the ordinary high watermark is entitled to riparian rights; however, 'ordinary high watermark' is not defined in the section. ${ }^{188}$ Ordinary high watermark is also not defined in Black's Law Dictionary ${ }^{189}$ or in the Florida Statutes section on land boundaries. ${ }^{190}$

The Florida Supreme Court has used the phrase 'ordinary high water mark' to describe the boundary between private and sovereign lands on navigable waters. ${ }^{191}$ The Florida Constitution uses the phrase 'mean high-water line' to describe the same boundary. ${ }^{192}$ Since the 'ordinary high watermark' and the 'mean high-water line' are both defined as the boundary between private and sovereign lands and both have been used in the same context in property disputes, it follows that they should have the same meaning. Therefore, the 'ordinary high watermark' is defined as 'the intersection of the tidal plane of mean high water with the shore;"193 and it represents the boundary between private and sovereign property on navigable waters. ${ }^{194}$

Much like littoral owners have a right to contact the mean high water line, ${ }^{195}$ littoral owners have a right to contact the ordinary high watermark. ${ }^{196}$ As the boundary between sovereign and private property gradually moves with the changing of the tide, the upland owner continues to own land up to and including the ordinary high watermark. ${ }^{197}$ The government, as owner of the property below the ordinary high watermark, receives a corresponding reciprocal benefit or burden depending on whether the line moves landward or seaward respectively. Although not called a right to accretions, this change in ownership is equivalent to the common law right to accretions and it is subject to the doctrine of avulsion. ${ }^{198}$

Although inherent in the Florida Constitution and in Florida Statutes, the statutory right to accretions has not been developed by

See Garner (n 1 above). Blacks Law Dictionary does define 'high-water mark' as '[t] he shoreline of a sea reached by the water at high tide ... usually computed as a mean or average high tide and not as the extreme height of the water.' Garner (n 1 above) 1730. This is consistent with the meaning of mean high-water line. See Fla. Stat. § 177.27(14) (2010).

190 See Fla. Stat. § 177.27 (2010) (providing definitions for the chapter on land boundaries).

191 Bd. of Trs. of the Internal Improvement Tr. Fund v Sand Key Assocs., Ltd., 512 So. 2d 934936 (Fla. 1987) ('[A] riparian or littoral owner owns to the line of the ordinary high water mark on navigable waters.'); accord State v Fla. Nat'( Props., Inc., 338 So. 2d 1317 (Fla. 1976); Hayes v Bowman 91 So. 2d 795799 (Fla. 1957); Brickell v Trammell 82 So. $221226-27$ (Fla. 1919); Thiesen v Gulf, Fla. \& Ala. Ry. Co., 78 So. 491 493-94 (Fla. 1918).

192 See Fla. Const. art. X, § 11.

193 See Fla. Stat. § $177.27(14)$ (2010).

194 Sand Key 512 So. 2d 936; Fla. Nat'l Props., 338 So. 2d 18-19; Thiesen 78 So. 493.

195 See text accompanying n 154-61 above.

196 See Fla. Stat. § 253.141 (2010).

197 See Fla. Stat. § 253.141 (2010)

198 See n 12 above. 
the courts. Prior to the Florida Supreme Court's decision in Walton County, the common law right to accretions was continually categorised as a vested right. ${ }^{199}$ The Walton County court reclassified the right as a contingent future right and cast doubt on the rights associated with owning littoral property. ${ }^{200}$ With the Beach and Shore Preservation Act authorising elimination of the right to accretions ${ }^{201}$ and nearly half of all Florida beaches being considered critically eroded, a significant portion of property owners are now at risk of losing the right to accretions. ${ }^{202}$ Recognition of the statutory right to accretions will increase the marketability of littoral property and restore consistency to an area of law that went unchanged for nearly a hundred years prior to Walton County. ${ }^{203}$ Considering that the right to accretions is based in both common law and the Florida Constitution, it should continue to be categorised as a vested right and courts should take notice of the statutory right to accretions.

\subsection{The avulsive event at issue}

As the Supreme Court correctly contends, an avulsive event will eliminate a littoral owner's right to accretions; ${ }^{204}$ however, the right is only permanently eliminated if the affected owner fails to take action and reclaim the land lost to the avulsive event. 205 The United States Supreme Court and the Florida Supreme Court both cite avulsive events as justification for eliminating the right to accretions; however, the courts do not cite to the same event. ${ }^{206}$

In Walton County, the Florida Supreme Court determined the beach restoration project was merely the state reclaiming 'stormdamaged shoreline' after a series of hurricanes. ${ }^{207}$ The court upheld the Beach and Shore Preservation Act because it authorised an act already allowed at common law, the reclamation of lands affected by an avulsive event. ${ }^{208}$

The United States Supreme Court cited the lower court's reclamation analysis but stated that ${ }^{209}$

See eg, Sand Key 512 So. $2 d 936$.

200 See Walton Cnty. $v$ Stop the Beach Renourishment, Inc., 998 So. 2d 1102 1118-20 (Fla. 2008).

201 Fla. Stat. 161.191 (2010)

202 See Bureau of Beaches and Coastal Systems (n 20 above).

203 See part 2.1 above.

204 Stop the Beach Renourishment, Inc. v Fla. Dep't of Envtl. Prot., 130 S. Ct. 2592 2612 (2010) (citing Walton Cnty., 998 So. 2d 1117 1120-21).

205 See State $v$ Fla. Nat'l Props., 338 So. 2d 13 18-19 (Fla. 1976).

206 Compare Stop the Beach Renourishment $130 \mathrm{~S}$. Ct. 2611-12 with Walton Cnty. 998 So. 2d 1117-18.

207 Walton Cnty., 998 So. 2d 1117-18.

208 Walton Cnty., 998 So. 2 d 1117-18.

209 Stop the Beach Renourishment 130 S. Ct. 2611-12. 
Florida law as it stood before the decision below allowed the State to fill in its own seabed, and the resulting sudden exposure of previously

submerged land was treated like an avulsion for purposes of ownership.

Even though the Supreme Court cited the Florida court's analysis, it relied on a different avulsive event as justification for eliminating the right to accretions.

The lower court's analysis hinges on the state's right to reclaim land lost to an avulsive event prior to the beach restoration project. ${ }^{210}$ In contrast, the Supreme Court's analysis hinges on the actual restoration project being the avulsive event that justifies eliminating the right to accretions. ${ }^{211}$ These two approaches result in significantly different analyses, neither of which provides an adequate justification for eliminating the littoral owners' right to accretions without paying just compensation. ${ }^{212}$

\subsubsection{The Florida Supreme Court erroneously held that reclaiming land lost to an avulsive event results in elimination of the littoral owners' right to accretions}

The Florida Supreme Court determined the avulsive event at issue was the reclamation of 'storm-damaged shoreline by adding sand to submerged sovereignty lands.' 213 The court relied on State v Florida National Properties, Inc. ${ }^{214}$ and held that the reclamation of lands through a beach restoration project did not constitute a taking of the upland owners' right to accretions. ${ }^{215}$ In Florida National Properties, littoral property owners utilised self-help dynamiting measures to lower water levels on Lake Istokpoga after a hurricane caused the water level to rise. ${ }^{216}$ The self-help measures did not lower the water level below the normal high-water mark, but rather, 'merely returned the water to its normal level and did not expose any lake bottom.'217 By lowering the water, the littoral property owners successfully reclaimed, within a reasonable time, the right to accretions and their land affected by the avulsive event. 218

The Florida Supreme Court failed to mention that the littoral property owners in Florida National Properties did not permanently lose the right to accretions. ${ }^{219}$ The property owners reclaimed the right to accretions because after the avulsive event and subsequent

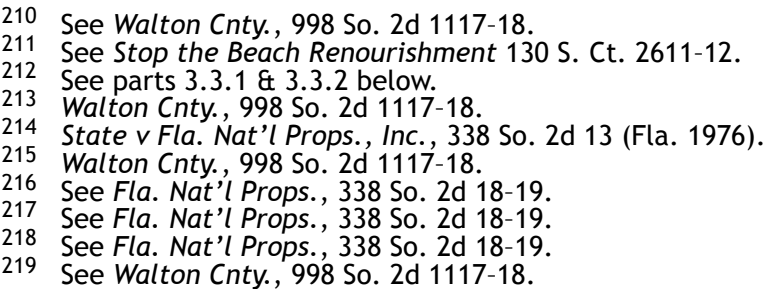


reclamation, the water returned to the pre-avulsive mean high-water line and there was no net effect on the property. ${ }^{220}$ It follows then that when, as the Florida Supreme Court contends is the case here, the state fills sovereign submerged lands pursuant to a beach restoration project in an attempt to 'reclaim' lands lost to an avulsive event, the reclamation eliminates the effect of the avulsive event and the right to accretions is preserved. ${ }^{221}$ Therefore, the reclamation of lands affected by the avulsive event that led to the beach restoration project cannot justify eliminating the littoral owners' right to accretions.

\subsubsection{The United States Supreme Court erroneously held that the state filling of sovereign submerged lands results in elimination of the littoral owners' right to accretions}

The United States Supreme Court relied on the beach restoration project as the avulsive event that justifies elimination of the littoral owners' right to accretions. ${ }^{222}$ While filling the seabed is a sudden and perceptible addition to land that is considered an avulsive event, the Court's analysis is flawed. The state does not have the right to fill sovereign submerged lands adjacent to littoral property it does not own. ${ }^{223}$ Much like a littoral owner cannot gain land through selfinduced artificial accretions, the government cannot eliminate a littoral owner's right to accretions by filling submerged lands it does not have the right to fill. ${ }^{224}$ As such, the doctrine of avulsion cannot justify taking the littoral owners' right to accretions without paying just compensation. ${ }^{225}$

Assuming arguendo, that the state does have the right to fill, the Court still erroneously held that such a right justifies taking the littoral owners' right to accretions. The state authorised filling of the seabed (the beach restoration project) had not occurred at the time the littoral owners' right to accretions was eliminated; therefore,

See Fla. Nat'l Props., 338 So. 2d 18-19.

See Fla. Nat'l Props., 338 So. 2d 18-19.

Stop the Beach Renourishment, Inc. v Fla. Dep't of Envtl. Prot., 130 S. Ct. 2592 2611-12 (2010) (stating that the right to accretions was not implicated by the Beach and Shore Preservation Act because the State's right to fill the seabed was superior to the littoral landowner's right to accretions, and because the doctrine of avulsion applied).

See part 3.1 above.

Compare Thiesen v Gulf, Fla. \& Ala. Ry. Co., 78 So. 491 506-07 (Fla. 1918); with $B d$. of Trs. of the Internal Improvement Tr. Fund v Medeira Beach Nominee, Inc. 272 So. 2d 209212 (Fla. Dist. Ct. App. 1973) ('[L]and below the ordinary high water mark is sovereignty land of the state, [and] to permit the riparian owner to cause accretion himself would be tantamount to allowing him to take state land.').

See Thiesen 78 So. 491. 
there was no avulsive event to justify the taking. ${ }^{226}$ Since the Court's proposed avulsive event of filling the seabed had not occurred at the time the right was eliminated, the Court should have disregarded the proposed filling and analysed whether there was a taking without just compensation on the date the right was eliminated.

\subsection{Establishing a fixed erosion control line constitutes a taking because it eliminates the littoral owners' vested right to accretions}

The Fifth Amendment Takings Clause - 'nor shall private property be taken for public use, without just compensation' 227 - applies to the taking of private property, including littoral rights. ${ }^{228}$ Regulatory takings jurisprudence 'aims to identify regulatory actions that are functionally equivalent to the classic taking in which government directly appropriates private property or ousts the owner from his domain.'229 A taking occurs when a regulation requires a property owner to submit to a permanent physical occupation, ${ }^{230}$ where the government deprives an owner of all economically beneficial use of his property, ${ }^{231}$ or where the government recharacterises private property as public property. ${ }^{232}$ While states have the ability to change property law, a state cannot transfer established, long recognised, and essential property rights from a citizen to the state without paying just compensation. 233

In Florida, littoral owners have a vested right to accretions ${ }^{234}$ that is an essential attribute to ownership of waterfront lands. ${ }^{235}$ The right has been long recognised and has gone without significant change

See Fla. Stat. § 161.191 (2010). The Beach and Shore Preservation Act eliminates the littoral owner's right to accretions upon recording the ECL in the county real property records-an event that occurs prior to the state filling the seabed. See Fla. Stat. § 161.191 (2010).

227 US Const. amend. v The Fifth Amendment applies against the states through the Fourteenth Amendment. Penn Cent. Transp. Co. v City of New York 438 US 104 122 (1978).

228 See Yates $v$ City of Milwaukee 77 US (10 Wall.) 497504 (1870); see also Thiesen 78 So. 507 ('Riparian rights ... are property, and, being so, the right to take it for public use without just compensation does not exist.'). The Florida State Constitution provides a similar limitation on government: "No private property shall be taken except for a public purpose and with full compensation.' Fla. Const. art. X, \& 6(a).

229 Lingle v Chevron USA Inc., 544 US 528539 (2005).

230 Loretto $v$ Teleprompter Manhattan CATV Corp., 458 US 419 435-36 (1982).

231 Lucas v S.C. Coastal Council 505 US 10031019 (1992).

232 Webb's Fabulous Pharmacies, Inc. v Beckwith 449 US 155 163-65 (1980).

233 Webbs's 449 US 163-65.

234 See part 3.2 above.

235 See eg, Thiesen v Gulf, Fla. \& Ala. Ry. Co., 78 So. 491507 (Fla. 1918). 
since $1766 .{ }^{236}$ As such, the right to accretions cannot be taken without just compensation. ${ }^{237}$

In accordance with the Beach and Shore Preservation Act, the littoral owners' common law right to accretions was eliminated and transferred to the government upon recording the erosion control line in the county real property records. ${ }^{238} \mathrm{At}$ no time prior to the transfer, or any time thereafter, did an avulsive event occur that would justify taking the littoral owners' vested right to accretions without paying just compensation. ${ }^{239}$ Additionally, the reclamation of lands affected by the avulsive event that led to the beach restoration project cannot justify eliminating the owners' right to accretions. ${ }^{240}$

As shown in Florida National Properties, and as is the case here, when there is no net effect after an avulsive event and a subsequent reclamation within a reasonable time, a state set fixed boundary for littoral property constitutes an unconstitutional taking. ${ }^{241}$ Setting such a boundary without the occurrence of a justifiable avulsive event eliminates the littoral owners' vested right to accretions and requires just compensation. ${ }^{242}$ Since the right to accretions is an essential and established right of littoral property owners and since no avulsive event justified elimination of the right, the government effectuated an unconstitutional taking of the right to accretions upon setting the ECL. ${ }^{243}$ As such, the Court's opinion in Stop the Beach Renourishment, Inc. v Florida Department of Environmental Protection was flawed, and the littoral property owners in that case should have been entitled to just compensation for the right to accretions.

\section{Conclusion}

In Stop the Beach Renourishment, Inc. v Florida Department of Environmental Protection, the United States Supreme Court

Bd. of Trs. of the Internal Improvement Tr. Fund $v$ Sand Key Assocs., Ltd., 512 So. 2d 934936 (Fla. 1987) (quoting Brickell v Trammell 82 So. 221227 (Fla. 1919)); see also Broward v Mabry 50 So. 826830 (Fla. 1909).

238 Fla. Stat. § 161.191 (2010) ("TT]he common law shall no longer operate to increase or decrease the proportions of any upland property lying landward of such line, either by accretion or erosion or by any other natural or artificial process.'). The statutory right to accretions discussed in part 3.2.2 has not been developed in case law. Although not explicit in the Beach and Shore Preservation Act, the upland property owner's common law right to accretions is transferred to the government upon recording the ECL. As the mean high-water line gradually and imperceptibly recedes seaward of the ECL and dry land is added to the shore of waterfront property, the boundary between private property and sovereign lands remains unchanged and the government retains title to the lands seaward of the erosion control line. See Fla. Stat. § 161.191 (2010).

241 See part 3.3.1 above.

242
See State v Fla. Nat'l Props., Inc., 338 So. 2d 13 18-19 (Fla. 1976).

See Fla. Nat'l Props., 338 So. 2 d 13 18-19. 
erroneously upheld Florida's Beach and Shore Preservation Act against a facial constitutional challenge. The Court used two conclusory paragraphs to set forth the background principles of Florida property law, ${ }^{244}$ and in doing so, misinterpreted Florida law at virtually every possible chance. A careful analysis of the cases relied on by the Court indicates the opposite of the Court's conclusion, that the State of Florida does not have the right to fill sovereign submerged lands adjacent to uplands it does not own. 245

Florida's Beach and Shore Preservation Act provides for elimination of the right to accretions without the occurrence of an avulsive event to justify such elimination. ${ }^{246}$ In erroneously upholding the Act and the Florida Supreme Court's decision, the United States Supreme Court contributed to the erosion of littoral rights in Florida. The right to accretions, which was previously classified as a vested right, ${ }^{247}$ is now considered a contingent future right that is far less valuable. ${ }^{248}$ With almost half of the beaches in Florida eligible for a beach restoration project, ${ }^{249}$ littoral owners in Florida are now at risk for losing the right to accretions. ${ }^{250}$ Considering its base in both common law ${ }^{251}$ and the Florida Constitution, ${ }^{252}$ courts need to recognise the right to accretions as a vested right and finally take notice of the statutory right to accretions.

243 It is also important to note that the Act contradicts the established rationale for the doctrine of accretions. Accretion is founded on the principle that "he who sustains the burden of losses and of repairs imposed by the contiguity of waters ought to receive whatever benefits they may bring by accretion.' See Bd. of Trs. of the Internal Improvement Tr. Fund v Medeira Beach Nominee, Inc., 272 So. 2d 209 212-13 (Fla. Dist. Ct. App. 1973) (citing St. Clair Cnty. v Lovingston 90 US (23 Wall.) 4667 (1874)). The Act provides for cancellation of the ECL when the 'governmental agency charged with the responsibility of maintaining the protected beach fails to maintain the same and as a result thereof the shoreline gradually recedes to a point or points landward of the erosion control line.' Fla. Stat. § 161.211 (2010). This provision contradicts Florida's rationale behind the doctrine of accretion because the government receives the benefit of receiving land by accretion but does not sustain the burden of losing land through erosion. Similarly, this provision of the Act also contradicts the rationale set forth by Blackstone. See Blackstone (n 31 above) 261-62 ("[A]nd besides, these owners being often losers by the breaking in of the sea, or at charges to keep it out, this possible gain is, therefore, a reciprocal consideration for such possible charge or loss.'). See Stop the Beach Renourishment, Inc. v Fla. Dep't of Envtl. Prot., 130 S. Ct. 2592 2611-12 (2010).

245 See part 3.1 above.

246 See parts 2.2 \& 3.3 above.

247 See part 3.2 above.

248 See Walton Cnty. $v$ Stop the Beach Renourishment, Inc., 998 So. 2d 1102 1118-20 (Fla. 2008).

249 See Fla. Stat. § 161.088 (2010); Bureau of Beaches and Coastal Systems (n 20 above).

250 See Fla. Stat. § 161.191 (2010).

251 See part 3.2.1 above.

252 See part 3.2.2 above. 
While the right to accretions is subject to the doctrine of avulsion, ${ }^{253}$ the Court incorrectly held that an avulsive event justified taking the littoral owners' right to accretions. The Court cited two different avulsive events as justification for eliminating the right to accretions; however, neither event provides such justification. ${ }^{254}$ The beach restoration project itself cannot provide justification for eliminating the right because the state does not have the right to fill, ${ }^{255}$ and at the time the right was eliminated, the beach restoration project had not taken place. ${ }^{256}$ The reclamation of lands lost to an avulsive hurricane also cannot justify eliminating the right because reclamation within a reasonable time preserves the right to accretions. ${ }^{257}$

Without the occurrence of a justifying avulsive event (or in the case of a reclamation within a reasonable time), a state set fixed boundary between private and sovereign property on navigable waters constitutes a taking of the upland owner's right to accretions. ${ }^{258}$ As such, the upland owners in Stop the Beach Renourishment, Inc. $v$ Florida Department of Environmental Protection should have been entitled to just compensation. 